DOI: https://doi.org/10.32839/2304-5809/2021-4-92-39

удК 37.013 .8

Бутенко А.С., Гром Т.В., Некрасов А.Д.

Військовий інститут телекомунікацій та інформатизації імені Героїв Крут

\title{
ЗМІСТ І СТРУКТУРА ПСИХОФІЗИЧНОЇ ВИТРИВАЛОСТІ МАЙБУТНІХ ОФІЦЕРІВ
}

Анотація. Стаття є дослідженням понять «витривалість», «психофізична витривалість». Обумовлено особливості психофізичної витривалості у студентів вищих військових закладів освіти. Розглянуто ключові компоненти психофізичної витривалості майбутніх офріцерів. Представлено наукове обгрунтування системи розвитку психофізичної підготовки майбутніх офіцерів. Зазначено пріоритетність розвитку фізичних якостей під час військово-спортивного тренування. Визначено роль раціональної методики розвитку фрізичних якостей в розвитку психофрізичної витривалості. Визначено класифікаційні ознаки спеціальної витривалості майбутніх офіцерів. Обумовлено особливості визначення психофрізіологічного статусу абітуріентів вищих військових закладів освіти як фундаменту подальшого розвитку психофрізичної витривалості майбутніх офіцерів.

Ключові слова: військовослужбовці, психофізіологія, підготовка, вищий військовий заклад освіти, потенціал.

Butenko Anton, Grom Tetiana, Nekrasov Andrew Military Institute of Telecommunications and Information Technologies named after Heroes of Kruty

\section{CONTENT AND STRUCTURE OF PSYCHOPHYSICAL ENDURANCE OF FUTURE OFFICERS}

Summary. The article is a study of the concepts of «endurance», "psychophysical endurance». The peculiarities of psychophysical endurance in students of higher military educational institutions are conditioned. The key components of psychophysical endurance of future officers are considered. The scientific substantiation of the system of development of psychophysical training of future officers is presented. Today, the issue of psychophysical endurance of future officers is insufficiently studied. The technique of development of structural components of psychophysical endurance of cadets needs detailed research. The main purpose of this work is to analyze the content and structural components of psychophysical endurance of future officers. The priority of development of physical qualities during military-sports training is specified. The role of rational methods of development of physical qualities in development of psychophysical endurance is defined. The classification features of special endurance of future officers are determined. The peculiarities of determining the psychophysiological status of entrants to higher military educational institutions as the foundation for further development of psychophysical endurance of future officers are conditioned. The meaningful components of approaches to increase the level of development of coordination abilities of future officers at the stage of initial professional and applied physical training are conditioned. The differences between the criteria for assessing the level of psychophysical readiness of future officers from the generally accepted ones are revealed. The leading and background components which promote formation of basic provisions of a technique of increase of necessary abilities are delimited. The value-motivational, cognitive, emotional-volitional, activity-practical and subjective components of the structure of psychophysical endurance of future officers are characterized.

Keywords: servicemen, psychophysiology, training, higher military educational institution, potential.

Постановка проблеми. В сучасних умо1 вах вдосконалення Збройних Сил України пред'являються все більш високі вимоги до психофрізичного потенціалу фрахівців військового профілю, зокрема до їх координаційним здібностям, які представляють собою складну структурно-фрункціональну систему, що складається із сукупності психічних і рухових (моторних) компонентів. Висока ступінь мобілізації та інтеграції психічних і моторних компонентів у структурі координаційної підготовленості забезпечує найбільш ефрективну і надійну психофрізичну готовність і придатність потенційних фрахівців до успішного вирішення поставлених завдань в імовірнісних та екстремальних умовах майбутньої військово-профресійної діяльності.

Аналіз останніх досліджень і публікацій. Окремі аспекти професійної витривалості висвітлені у дослідженнях щодо психологічної витривалості (В. Бодров, І. Воробйова, Е. Зеєр, О. Дьомін, О. Колесніченко, Я. Мацегора, Н. Пенькова та ін.), м’язової витривалості (В. Ільїнич, Я. Кру- шельницька, Т. Круцевич, В. Платонов, Р. Раєвський та ін.), витривалості нервової системи (М. Веденський, Н. Бернштейн, І. Павлов, I. Сеченов, О. Ухтомський). Дослідники Є. Гаркавцев, М. Гритченко, С. Канішевський, Я. Крушельницька, О. Колесніченко, В. Метелицький, Н. Пенькова, Р. Раєвський та ін., розглядають професійну витривалість лише як компонент більш складної системи, при цьому не висвітлюють її сутнісну та змістовну характеристику.

Виділення невирішених раніше частин загальної проблеми. На сьогодні проблематика психофізичної витривалості майбутніх офіцерів $\varepsilon$ недостатньо вивченою. Потребує детального дослідження методика розвитку структурних компонентів психофізичної витривалості курсантів.

Мета дослідження. Головною метою ціеї роботи є проаналізувати змістовне наповнення і структурні компоненти психофрізичної витривалості майбутніх офріцерів.

Виклад основного матеріалу. Наукове обIрунтування системи розвитку психофрізичної під- 
готовки майбутніх офіцерів обумовлено систематичним ускладненням військової техніки та озброєння, оптимізації тактики бойових дій, переходом до профресійної армї, що обумовлюе завищені вимоги до рівня рухових, фрункіональних і психічних кондицій особового складу для едрективного оволодіння різними військовими спеціальностями).

Розвиток фрізичних якостей є одним 3 пріоритетних позищій в теорії і практищі військовоспортивного тренування. Існують різні підходи науковців-практиків і дослідників стосовно змістовного наповнення методики виховання фрізичних якостей. Ращіональна методика розвитку dрізичних якостей в юнацькому віці $е$ надійним фундаментом для подальшого розвитку психофізичної витривалості з метою досягнення значних результатів в військовій сфрері.

Витривалість розглядаеться як здатність людини едрективно здійснювати цілеспрямовані дії, в умовах природної психофізіологічної втоми, у порівнянні 3 іншими фрізичними характеристиками, наприклад, силою і швидкістю, витривалість $\epsilon$ більш багатокомпонентною характеристикою. Окрім загальної (базової) виокремлюють також силову витривалість, швидкісну витривалість, координаційну, а також витривалість локальних груп м'язів. Всі демонстраціі витривалості обумовлені мірою узгодженості в роботі більшості органів і систем організму. Витривалий організм повинен мати у своєму розпорядженні можливості ресинтезу енергії різних типів, мати здатність витрачати зазначені ресурси таким чином, щоб їх було достатньо на виконання значної кількості цілеспрямованої фрізичної роботи без серйозної шкоди для життя та здоров'я майбутніх офіцерів.

Спеціальна витривалість класифікуеться: за ознаками рухової дії, за допомогою якої вирішується рухове завдання (наприклад, стрибкова витривалість): по ознакам рухової діяльності, в умовах якої вирішуеться рухове завдання (наприклад, ігрова витривалість): за ознаками взаємодії 3 іншими фізичними якостями (здібностями), необхідними для успішного вирішення рухового завдання (наприклад, силова витривалість, швидкісна витривалість, координаційна витривалість і т.д.).

Р. Раєвським і С. Канішевським професійна витривалість визначається як окремий критерій спеціальної профресійно-прикладної фрізичної підготовки, що може бути оцінена за мірою здатності особи виконувати задане фрізичне навантаження 3 потрібною нервово-психічною стійкістю, у визначеному робочому режимі й темпі, без значних ознак втоми чи помилок [6, с. 255]. B. Аредьев фрізичну витривалість трактуе як здатність організму протистояти втомі, що надає можливість тривалий час підтримувати потрібний рівень інтенсивності рухової діяльності, виконувати значний обсяг фрізичних вправ, швидко відновлювати сили після навантажень [1, с. 88].

Фізична підготовка $є$ одним 3 основних компонентів психофрізичної підготовки військовослужбовців всіх категорій. Витривалість є базовою фрізичною якістю в профресійно-прикладній фрізичній підготовці офріцерського складу Збройних Сил. У той же час рівень їі розвитку, в порівнянні 3 іншими руховими якостями, у військовослужбовців є найбільш низькою, за роки незалежності
України витривалість оцінюеться «незадовільно». У майбутніх офріцерів серед основних фрізичних якостей найбільш відстаючою є витривалість. Рівень фрізичного розвитку і фрізичної підготовленості, майбутніх офріцерів не відповідає сучасним вимогам, і мають негативну тенденщію. Такий стан $є$ результатом недостатньої якості фрізичного виховання школярів і допризовної молоді.

При продесійному відборі кандидатів для вступу до вищого військового закладу освіти потрібно визначати психофрізіологічний статус особистості абітурієнта. Функціональні резерви серцево-судинної системи, резистентність до фрізичного навантаження у абітуріента має бути обумовлені під час проведення вступного випробування з фрізичної підготовки. В процесі проходження абітурієнтом військово-лікарської комісії необхідно визначення особливостей внутрішньо судинного компонента мікроциркуляції, вегетативного статусу, стану тонусу центрів вегетативної нервової системи з метою оптимізації профресійного відбору в вищих військових закладах освіти.

Зміст розроблених методичних підходів до підвищення рівня розвитку координащійних здібностей майбутніх офріцерів на етапі початкової професійно-прикладної фрізичної підготовки полягає:

- у введенні резервно-компенсуючих занять координаційної спрямованості з акцентованим і рівномірним розподілом тренувальних засобів, які впливають на провідні і фонові компоненти КС;

- підборі та розробці комплексу поліструктурних і поліфункціональних засобів фрізичного виховання, спрямованих на підвищення загальних, спеціальних і специфічних координаційних здібностей;

- в динамічному підвищенні тренувального навантаження за параметрами: обсяг, інтенсивність, тривалість інтервалів відпочинку, кількість повторень, координаційна складність вправи.

Виявлені кількісні (точність, швидкість, економічність, стабільність) i якісні (адекватність, своєчасність, доцільність, ініціативність) критерії оцінки рівня прояву психофрізичної підготовленості майбутніх офріцерів до військово-професійної діяльності відрізняються від загальноприйнятих, які дозволяють розробити алгоритм у вигляді експертної інформаційнодіагностичної системи для віднесення майбутніх військових фрахівців до ряду спеціальностей військової сфрери, і підводять до обгрунтування програмно-методичного забезпечення резервнокомпенсуючих занять координаційної спрямованості на етапі початкової психофізичної підготовки з орієнтацією на підвищення професійно важливих психофізичних якостей, сприяють формуванню готовності і придатності курсантів до майбутньої служби в Збройних Силах.

Розмежовують провідні (здатність до перебудови і пристосування рухових дій, до орієнтування в просторі, до швидкого реагування, до точності відтворення, диференціювання, відмірювання та оцінювання силових параметрів руху і до узгодження рухових дій) і фронові (здатність до підтримання статичної і динамічної рівноваги, до збереження і зміни ритмічної структури руху, до вестибулярної стійкості і до довільного м'язового розслаблення) компоненти, що забезпечують формування основних положень методики під- 
вищення вищеназваних здібностей, заснованих на акцентованому і рівномірному розподілі тренувальних засобів на етапі початкової психофізичної підготовки майбутніх офріцерів 3 позищій структурної організації рухової діяльності у військово-профресійної сфрері.

Структуру психофізичної витривалості майбутніх офіцерів будуть складати такі компоненти: ціннісно-мотиваційний, когнітивний, емоційновольовий, діяльнісно-практичний і суб'єктний.

Ціннісно-мотиваційний компонент психодрізичної витривалості включає мотивацією до навчально-пізнавальної діяльності, що характеризуеться групами мотивів відносно їі розвитку; домінуванням профресійних цінностей; ціннісним осмисленням психофрізичної витривалості як інструменту збереження і оптимізації стану здоров'я, зростання якості життя та результативності продресійної самореалізації [4].

Когнітивний компонент психофрізичної витривалості обумовлений системою науково-теоретичних знань 3 психофрізичної витривалості відносно особливостей майбутньої військової діяльності; засвоєння знань про форми, інструменти і методи розвитку психофрізичної витривалості; знаннями відносно самостійного розвитку психофізичної витривалості.

Діяльнісно-практичний компонент психофрізичної витривалості сприяє реалізації практичної підготовки до фрахової діяльності. В даному сенсі отримали відображення практичні здібності відносно застосування здобутих знань на практиці; уміння засвоювати ефективні прийоми, техніки й інструменти розвитку психофрізичної витривалості; уміння реалізувати самоконтроль, самоаналіз і самооцінку сформованості психофізичної витривалості; здатність регулювати та сприймати фрізичні та психологічні навантаження.

Емоційно-вольовий компонент психофізичної витривалості спрямований на подолання внутрішніх i зовнішніх перешкод, що з'являються в ході розвитку психофрізичної витривалості, створюють фрундамент для їі реалізації за рахунок активізації слухачів, актуалізащії в них таких якостей як рішучість, дисциплінованість, цілеспрямованість орієнтованих на позитивне мислення та самоповагу. Зазначений складник характеризується задоволенням від процесу і результату психофрізичної витривалості; емощійною здатністю до розвитку психофізичної витривалості; рівнем прояву та генералізації вольових якостей.

Суб'єктний складник психофрізичної витривалості $е$ специфічним відображенням змісту зазначених компонентів, усвідомлення того що майбутній офіцер як суб'єкт освітньої та фрахової діяльності, сам управляе ходом розвитку психофізичної витривалості, визначає модель майбутнього офріцера, співвідносить себе 3 іншими учасниками освітнього процесу. Цей компонент характеризується усвідомленою доцільністю розвитку психофрізичної витривалості; саморедрлексією, самооцінюванням та самомобілізуванням в ході розвитку психофрізичної витривалості; здатністю до відповідальності за підсумки власної психофізичної витривалості [2].

Уміння проводити велику кількість складних технічних i тактичних дій, облік можливих дій противника, прийняття сміливих і миттевих рі- шень в екстремальних ситуащіях на тлі впливу різноманітних фракторів - все це $є$ необхідною умовою для досягнення успіху в військовій сдрері та відображає рівень їх психофрізичної підготовленості [1].

Психофізіологічні фрункції майбутніх офріцерів залежать від особливостей вищої нервової системи, що характеризують процес форомування та вдосконалення спеціальних рухових навичок в умовах військової діяльності [3]. Також, фрізична підготовленість майбутніх офріцерів є однією 3 найважливіших основ загальної структури їх підготовленості, що визначає рівень спеціальної працездатності, від якої залежить надійність реалізації технічних дій.

Надмірна тренованість обумовлюеться дисбалансом між навантаженням і відновленням. Під час перенапруги i перетренованості обумовлюється певними порушеннями, що обумовлюються на межі з хворобливими порушеннями, при цьому мають місце фрнкціональні, а іноді і органічні зміни в організмі курсантів які призводять до значного і тривалого зниження його працездатності, розвитку гострого і хронічного стомлення, при цьму варто відзначити підвищену збудливість, нестійкість настрою, небажання тренуватися, млявість [2].

Переважання процесів гальмування, в свою чергу, уповільнюе відновлювальні процеси. Погіршення психофрізичної підготовленості - основний прояв хронічної втоми. Необхідний рівень психофрізичної витривалості може підтримуватися лише короткочасно за рахунок підвищення біологічної ціни і швидкого витрачання фрункціональних резервів організму.

У високопідгоовлених кадетів розвиток гострих i хронічних дрорм стомлення в умовах тривалих інтенсивних фрізичних i психологічних навантажень може сорормуватися синдром хронічної втоми. Цьому явищу передують ранні зміни фрункціонального, психофрізіологічного i психічного стану майбутнього офріцера, розвиток перетренованості і хронічної втоми. Необхідний постійний контроль психофрізичного стану кадетів на тлі проведених інтенсивних, об'ємних тренувальних навантажень. При появі ранніх ознак хронічної втоми, якщо не внести корективи в процес підготовки виникають і багатофункціональні зміни в організмі.

Виявлення цих ранніх змін може сприяти виділенню груп ризику і розробщі методів профілактики хронічної втоми і синдрому хронічної втоми на основі корекції навантажень [2].

Висновки і пропозиції. У ході наукового дослідження було виявлено та обгрунтовано змістовне наповнення та компоненти психофрізичної витривалості майбутніх офріцерів. Проведення комплексного наукового аналізу, структурування інфрормації, сприяло характеристиці важливості розвитку психодрізичної витривалості майбутніх офіцерів. Для покращення рівня психофрізичної витривалості майбутніх офріцерів доцільно переглянути програму фізичного виховання старших школярів 3 метою зменшення різниці у кількісних та якісних критеріях відбору абітурієнтів.

Перспективи подальших наукових досліджень полягають у визначенні методики проведення комплексного дослідження розвитку психофрізичної витривалості майбутніх офріцерів. 


\section{Список літератури:}

1. Арефьєв В. Г. Основи теорії та методики фрізичного виховання. Кам'янець-Подільський, 2011. 368 с.

2. Вербин Н. Б. Сутність, зміст і структура професійної витривалості майбутніх магістрів військового управління на етапі оперативно-тактичного рівня підготовки. Вісник Житолирського державного університету імені Івана Франка. Педагогічні науки. 2017. № 2. С. 51-55.

3. Дьомін О. А. Навчальний процес і інтелектуальна витривалість студентів. Науковий вісник Національного університету біоресурсів і природокористування Украӥни. Серія : Педагогіка, психологія, ббілособія. 2013. № 192(1). C. 136-142.

4. Костів С. Критерії, показники і рівні оцінювання розвитку психофізичної витривалості майбутніх професіоналів військового управління. Військова освіта. 2018. № 1. С. 166-173.

5. Лавриненко В. В. Развитие общей вуносливости в короткие сроки для повушения профессиональной работоспособности курсантов окружнух учебнух центров : авторефр. ... канд. пед. наук : 13.00.04. Санкт-Петербург : [б. и.], 2005. $24 \mathrm{c.}$

6. Примак П. Т. Особливості дослідження психологічної підготовленості особового складу миротворчих частин та підрозділів. Наукові записки Інституту психології імені Г. С. Костюка АПН України. Київ : ДП «Інформаційно-аналітичне агентство», 2007. № 35. С. 407-414.

\section{References:}

1. Arefiev V. H. (2011) Osnovy teorii ta metodyky fizychnoho vykhovannia [Fundamentals of the theory of methods of physical wickedness]. Kamianets-Podilskyi, $368 \mathrm{p}$.

2. Verbyn N. B. (2017) Sutnist, zmist i struktura profesiinoi vytryvalosti maibutnikh mahistriv viiskovoho upravlinnia na etapi operatyvno-taktychnoho rivnia pidhotovky [Sutness, change and structure of professional vitality of future masters of military management at the stage of operational-tactical training]. Visnyk Zhytomyrskoho derzhavnoho universytetu imeni Ivana Franka. Pedahohichni nauky, vol. 2, pp. 51-55.

3. Domin O. A. (2013) Navchalnyi protses i intelektualna vytryvalist studentiv [Educational process and intellectual vitality of students]. Naukovyi visnyk Natsionalnoho universytetu bioresursiv i pryrodokorystuvannia Ukrainy. Seriia: Pedahohika, psykholohiia, filosofiia, vol. 192(1), pp. 136-142.

4. Kostiv S. (2018) Kryterii, pokaznyky i rivni otsiniuvannia rozvytku psykhofizychnoi vytryvalosti maibutnikh profesionaliv viiskovoho upravlinnia [Criteria, indicators and indicators and evaluation of the development of psychophysical vitrification of the future professionals in the field of management]. Viiskova osvita, vol. 1, pp. 166-173.

5. Lavrynenko V. V. (2005) Razvytye obshchei vynoslyvosty v korotkye sroky dlia povyshenyia professyonalnoi rabotosposobnosty kursantov okruzhnykh uchebnykh tsentrov [Development of general endurance in a short time to improve the professional performance of cadets of district training centers]: avtoref. ... kand. ped. nauk: 13.00.04. Sankt-Peterburh, $24 \mathrm{p}$.

6. Prymak P. T. (2007) Osoblyvosti doslidzhennia psykholohichnoi pidhotovlenosti osobovoho skladu myrotvorchykh chastyn ta pidrozdiliv [Development of general endurance in a short time to improve the professional performance of cadets of district training centers]. Naukovi zapysky Instytutu psykholohii imeni H. S. Kostiuka APN Ukrainy. Kyiv: DP «Informatsiino-analitychne ahentstvo», vol. 35, pp. 407-414. 